\title{
RANCANGAN APLIKASI PELAYANAN JASA PENCUCIAN PADA TENTRAM LAUNDRY
}

\author{
Lawren Josua Hutapea ${ }^{1}$, Prihastanto ${ }^{2}$, Thomas Afrizal ${ }^{3}$ \\ ${ }^{1,2,3}$ Teknik Informatika, Fakultas Teknik dan Ilmu Komputer, Universitas Indraprasta PGRI Jakarta \\ Jalan Raya Tengah No 80, Kelurahan Gedong, Pasar Rebo, Jakarta Timur \\ 1'awrenjosuahutapea@gmail.com, ${ }^{2}$ prihastanto@gmail.com, ${ }^{3}$ thomztaurus@gmail.com
}

\begin{abstract}
ABSTRAK
Tentram Laundry salah satu laundry kiloan yang berada di Jatijajar - Depok. Letaknya yang strategis tepatnya di jln Perumahan Jatijajar Tapos Kota Depok, membuat banyak pelanggan yang berkunjung setiap hari untuk menggunakan jasa Tentram Laundry. Permasalahan yang terdapat pada Tentram Laundry adalah sering terjadinya kehilangan berkas pada saat pelaporan bulanan kepada pimpinan diakibatkan human error dan pencatatan data pelanggan dan pembuatan nota transaksinya masih dicatat pada lembaran kertas menggunakan tulisan tangan dan juga ada disimpan pada map (stell helder). Tujuan merancang suatu sistem informasi pelayanan jasa pencucian ini dengan tujuan untuk memudahkan admin dalam memproses pengolahan data yang ada saat ini. Perangkat aplikasi yang telah dibuat dengan bahasa pemrograman Java NetBeans 8.0.2 dan penyimpanan data pada database MySQL dapat memberikan kelancaran dalam proses menginput dan penyimpanan data-data serta laporan-laporan yang diberikan kepada pemilik Tentram Laundry. Dengan menggunakan metode penelitian Research and Development diharapakan mampu menyelesaikan permasalahan yang ada. Hasil dari penelitian ini merancang aplikasi yang dapat memproses data pelanggan serta pelayanan jasa pencucian pada Tentram Laundry secara terkomputerisasi yang membantu admin sehingga menghasilkan laporan yang tersimpan dengan baik dan memberikan hasil secara cepat dan akurat.
\end{abstract}

Kata Kunci: Aplikasi, Pelayanan, Pencucian, Desktop

\begin{abstract}
Tentram Laundry is one of the kilogram laundry located in Jatijajar - Depok. Its strategic location, precisely on Jln. Jatijajar Tapos Housing, Depok City, makes many customers who visit every day to use the services of Tentram Laundry. The problem with Tentram Laundry is the frequent occurrence of file loss during monthly reporting to the leadership due to human error and recording customer data and making transaction notes that are still recorded on sheets of paper using handwriting and are also stored on a map (stell helder). The purpose of designing an information system for this washing service is to make it easier for admins to process the current data processing. The application device that has been made with the Java NetBeans 8.0.2 programming language and data storage in the MySQL database can provide a smooth process of inputting and storing data and reports provided to the owner of Tentram Laundry. By using the Research and Development research method, it is expected to be able to solve the existing problems. The results of this study design applications that can process customer data and computerized washing services at Tentram Laundry which help admins to produce reports that are stored properly and provide results quickly and accurately.
\end{abstract}

Key Word: Application, Service, Washing, Desktop

\section{PENDAHULUAN}

Perkembangan teknologi informasi pada masa sekarang sangat berperan penting untuk membantu permasalahan dalam proses suatu kegiatan (Husnil Kamil, 2016), salah satunya di bidang usaha/bisnis Usaha laundry merupakan sebuah bisnis yang berkaitan dengan pelayanan jasa pencucian pakaian dengan mesin cuci maupun mesin pengering otomatis dan cairan pembersih serta pewangi khusus. Bisnis ini menjamur di kota-kota besar yang banyak terdapat rumah kost, rumah kontrakan dan perumahan, dimana penyewa kost atau kontrakan tidak sempat atau tidak bisa melakukan cuci dan setrika baju sendiri dikarenakan kesibukan sebagai mahasiswa maupun pekerja. Tentram Laundry salah satu laundry kiloan yang berada di Jatijajar - Depok (Niroha et al., 2016) .

Letaknya yang strategis tepatnya di jln Perumahan Jatijajar Tapos Kota Depok, membuat banyak pelanggan yang berkunjung setiap hari untuk menggunakan jasa Tentram Laundry. Namun dibalik kemajuan teknologi informasi yang kini telah berkembang secara pesat, Tentram Laundry belum mempunyai 
system penyimpanan database yang akurat sehingga semua data masih disimpan ke dalam sebuah buku. Pencatatan transaksi dan pengelolaan data dilakukan masih menggunakan nota, sehingga untuk melakukan pencarian data sangat memakan waktu yang lama dan kurang akurat (Haqi, 2018). Selain itu sering terjadinya data barang yang tidak terkontrol, pembuatan laporan masih relatif lama karena masih menggunakan proses manual yaitu dengan tulis tangan (Andriansyah, 2018).

Jasa pelayanan merupakan setiap tindakan atau kegiatan yang dapat ditawarkan oleh satu pihak kepada pihak lain, pada dasarnya tidak berwujud dan tidak mengakibatkan kepemilikan apapun (Kotler, 2016).

Perancangan sistem informasi yang akan diterapkan dapat memudahkan dalam pengolahan data sehingga mendapatkan manfaat yaitu membantu pengolahan data secara terkomputerisasi untuk memudahkan dan mempercepat proses transaksi, memudahkan pencarian data, memudahkan pembuatan laporan dan meminimalisir kesalahan proses pencatatatn transaksi (Bonny Triangga, 2015).

Dengan permasalahan tersebut, perlu ada nya suatu sistem yang terkomputerisasi dalam penyelesaiannya. Sistem adalah sekelompok unsur yang erat hubungannya satu dengan yang lain, yang berfungsi bersama-sama untuk mencapai tujuan (Sutabri, 2012). Sistem merupakan suatu kumpulan dari komponen-komponen yang membentuk satu kesatuan (Tyoso, 2016). Pembangunan sistem adalah sekumpulan aktivitas yang menggambarkan secara rinci bagaimana sistem akan berjalan. Hal itu bertujuan untuk menghasilkan produk perangkat lunak yang sesuai dengan kebutuhan user (Satzinger, J. W., Jackson, R. B., Burd, n.d.).

Diharapkan dengan adanya suatu sistem informasi dapat menangani permasalahan yang ada di perusahaan tersebut. Sistem adalah setiap sesuatu terdiri dari obyek-obyek, atau unsur-unsur, atau komponen-komponen yang bertata kaitan dan bertata hubungan satu sama lain, sedemikian rupa sehingga unsurunsur tersebut merupakan satu kesatuan pemrosesan atau pengolahan yang tertentu. (Prasojo, 2011)

Aplikasi ini dapat memudahkan pekerjaan Admin dalam melaksanakan pembuatan laporan dan dapat memudahkan karyawan dalam memberikan pelayanan jasa pencucian yang maksimal serta memudahkan dalam penginputan data serta pencarian data yang ada pada Tentram Laundry.

\section{METODE PENELITIAN}

Peneliti menggunakan metode Research and Development dalam penyelesaian penelitian ini. (Sugiyono, 2016). Dalam pelaksanaan $\mathrm{R} \& \mathrm{D}$, ada beberapa metode yang digunakan yaitu metode deskriptif, evaluatif dan eksperimental. Metode penelitian deskriptif digunakan dalam penelitian awal untuk menghimpun data tentang kondisi yang ada yaitu penulis membutuhkan data-data yang dapat menunjang tercipta nya suatu sistem aplikasi pelayanan jasa pencucian seperti data pelanggan, data petugas, data pencucian dan data harga terdahulu yang masih tersimpan secara manual didalam buku besar. Metode evaluatif digunakan untuk mengevaluasi proses ujicoba pengembangan suatu produk, dalam proses ini penulis melakukan ujicoba terhadap suatu sistem yang telah dirancang agar tidak ada terjadi kesalahan dalam proses penginputan data serta pelaporan bulanan kepada pemilik. Dan metode eksperimen digunakan untuk menguji keampuhan dari produk yang dihasilkan, dalam proses yang terakhir ini perlu dilakukan pengujian akhir yang diharapkan bahwa sistem yang dirancang oleh penulis dapat berjalan dengan baik dan sesuai dengan kebutuhan dan terfokus pada proses pendataan pelayanan jasa pencucian pada Tentram Laundry (Putra, 2011).

\section{HASIL DAN PEMBAHASAN Analisa Permasalahan}

Analisis permasalahan yang dapat peneliti simpulkan dari hasil penelitian yang dilakukan di Tentram Laundry adalah bahwa, instansi ini termasuk salah satu instansi yang belum memiliki sistem informasi berbasis komputerisasi dalam pengolahan data pelayanan jasa laundry dan managemen data pelanggan, sehingga dirasakan masih sangat membutuhkan sistem yang mampu dan memberikan kemudahan bagi bagian yang 
terkait dalam sistem pengolahan data pelayanan jasa laundry. Ada beberapa permasalahan yang dimiliki oleh pihak instansi antara lain, pelayanan jasa yang masih dilakukan pencatatan secara manual dengan menggunakan berkas sehingga menyulitkan karyawan ketika akan melakukan pencarian data ataupun pengarsipan data. Pencatatan pelayanan jasa yang berjalan belum maksimal karena penggunaan berkas sebagai sarana pencatatan pelayanan jasa. Dalam proses pengarsipan pelayanan jasa masih menggunakan pencatatan buku besar sehingga petugas sering kesulitan mencari data pelayanan jasa.

Dalam sistem pelayanan jasa yang berjalan, sering terjadi kehilangan data yaitu tidak ditemui berkas penunjang untuk membuktikan bahwa pelanggan sudah melakukan pembayaran administrasi. Pelaporan pelayanan jasa yang sering terlambat karena banyaknya data yang harus di input dan disetorkan oleh karyawan yang bersangkutan karena masih mencatat dengan menggunakan worksheet. Kendala dari setiap tugas-tugas karyawan adalah pada saat mengerjakan tugas-tugas tersebut masih mebutuhkan waktu yang cukup lama.

\section{Alternatif Penyelesaian Masalah}

Alternatif penyelesaian masalah yang peneliti usulkan adalah dengan membuat sebuah aplikasi sistem pelayanan dan managemen data pelanggan dengan menggunakan bahasa pemrograman Java dan penyimpanan datadata pada media database. Dengan adanya aplikasi ini diharapkan mampu memberikan kontribusi yang positif bagi kemajuan dalam pengolahan data-data pelayanan jasa laundry. Proses pencarian data tidak lagi membutuhkan waktu yang lama karena datadata pelayanan jasa laundry yang ada sudah tersimpan pada media database. Dengan usulan ini diharapkan permasalah pada pengolahan data-data pelayanan jasa laundry dapat tertangani dengan cepat dan akurat (Christian, Rizal, Alam, \& Amir, 2019).

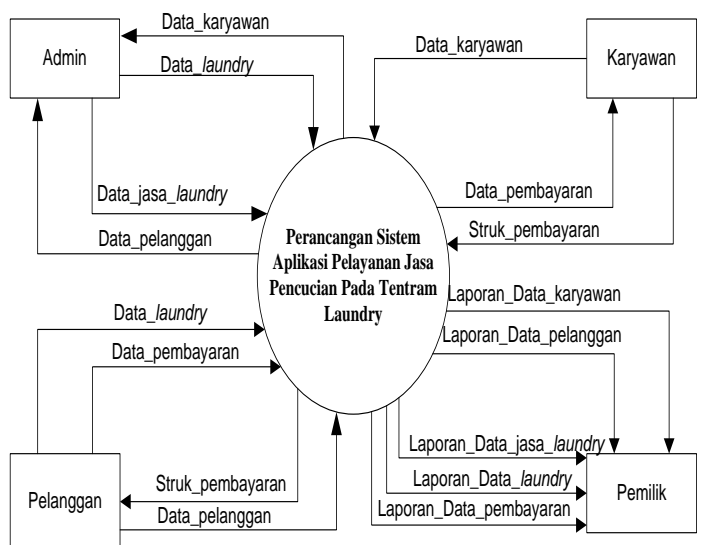

Gambar 1. Diagram Konteks

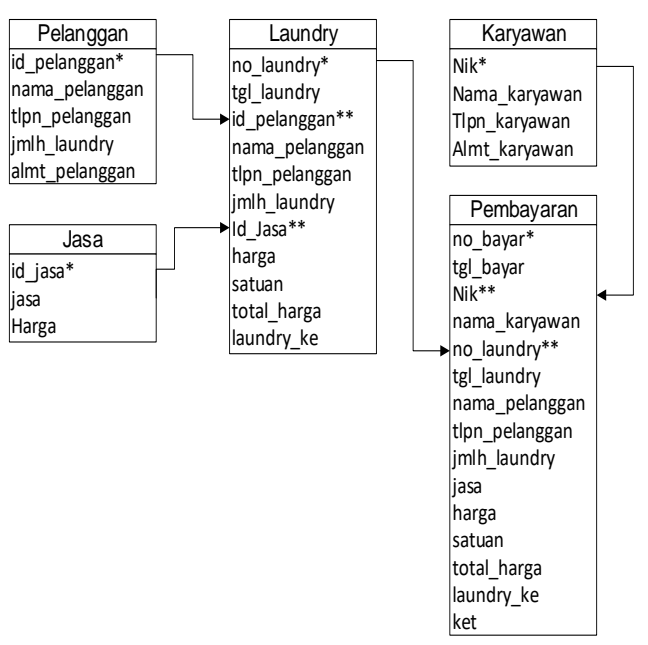

Gambar 2. Normalisasi

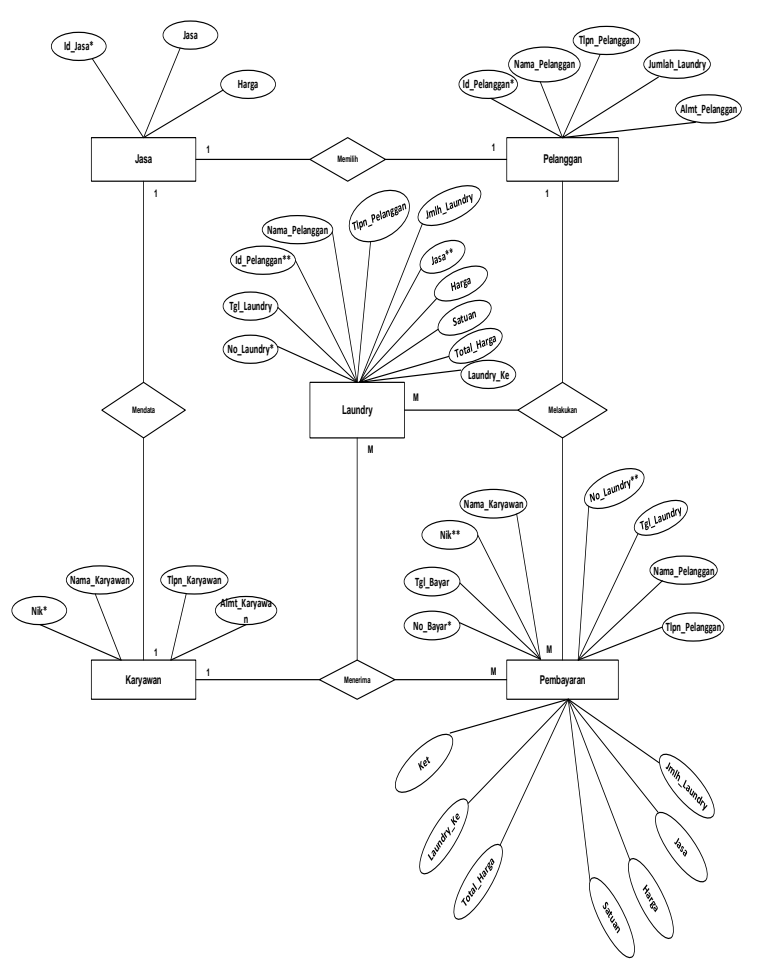

Gambar 3. ERD (Entity Relationship Diagram) 
Berikut adalah tampilan layar dan hasil pengujian pada software program yang telah di buat dengan bahasa pemrograman Java.

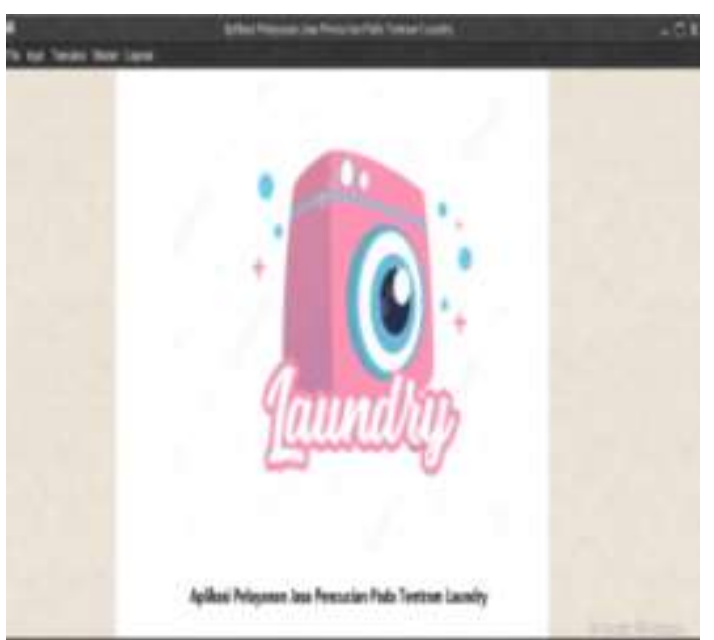

Gambar 4. Form Menu Utama

Layar di atas menampilkan tampilan Menu Utama pada Aplikasi Pelayanan Jasa Pencucian Pada Tentram Laundry. Pada layar utama tersedia menu bar yang terdiri dari master data yang digunakan untuk memasukkan data yang berkaitan dengan data karyawan, data jasa cuci, data transaksi cuci, data pembayaran dan laporan-laporan serta nota transaksi cuci dan nota pembayaran.

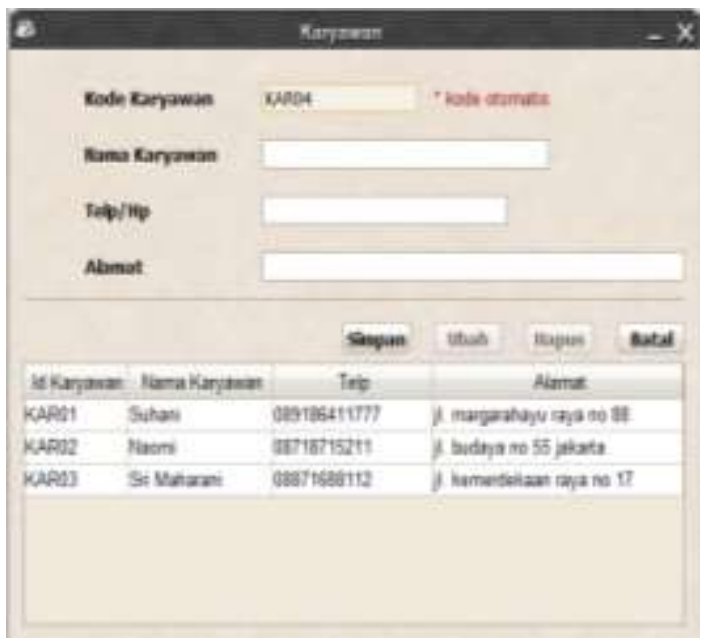

Gambar 5. Form Data Karyawan

Layar di atas menampilkan tampilan form data karyawan. Pada layar form data karyawan untuk meng-input data karyawan yang terdiri dari Kode Karyawan, Nama Karyawan, No Telp dan Alamat.

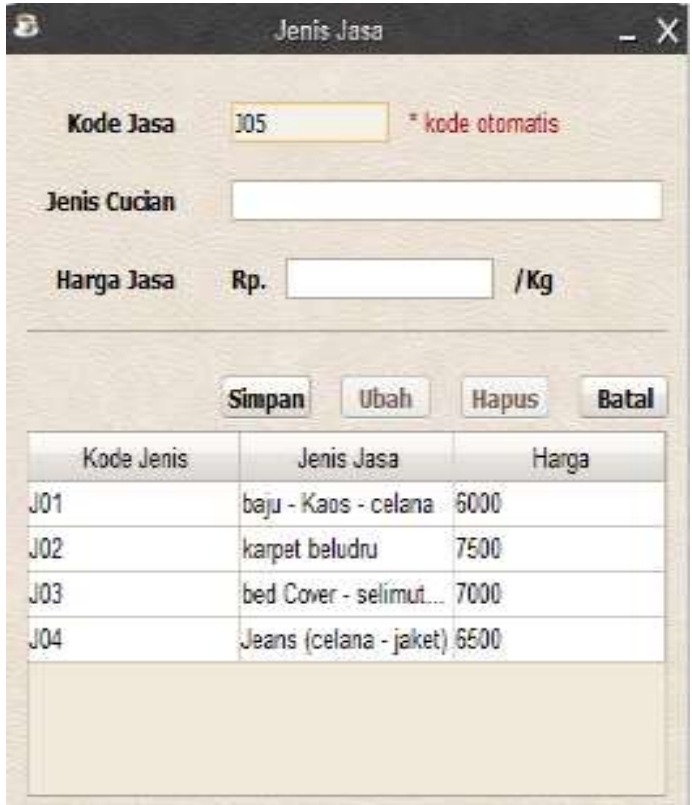

Gambar 6. Form Data Jasa Cuci

Layar di atas menampilkan tampilan form data jasa cuci. Pada layar form data jasa cuci untuk meng-input data jasa cuci yang terdiri dari Kode Jasa, Jenis Cucian, dan Harga Jasa.

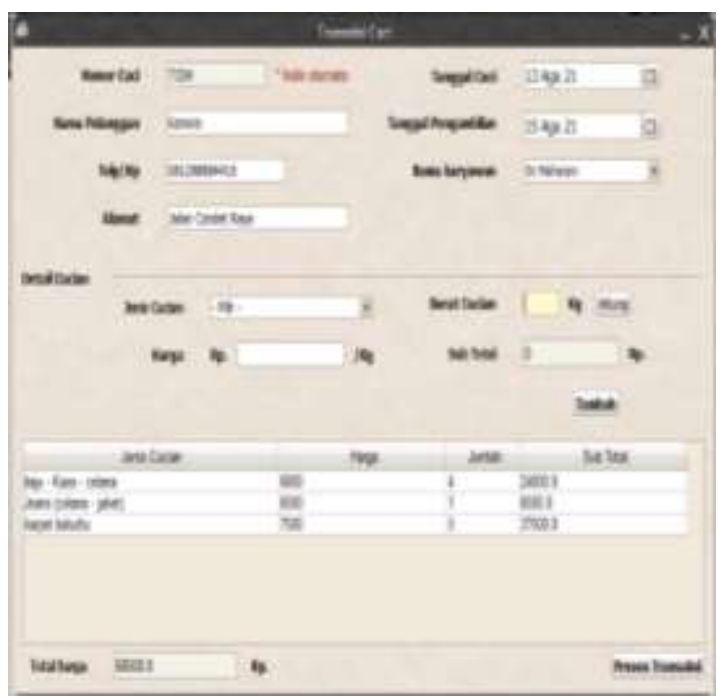

Gambar 7. Data Form Data Transaksi

Layar di atas menampilkan tampilan form data transaksi. Pada layar form data transaksi untuk meng-input data transaksi yang terdiri dari Nomor Cuci, Nama Pelanggan, No Telp, Alamat, Tgl Cuci, Tgl Pengambilan, Nama Karyawan, Jenis Cucian, Harga, Berat Cucian, Sub Total, dan Total Harga. 


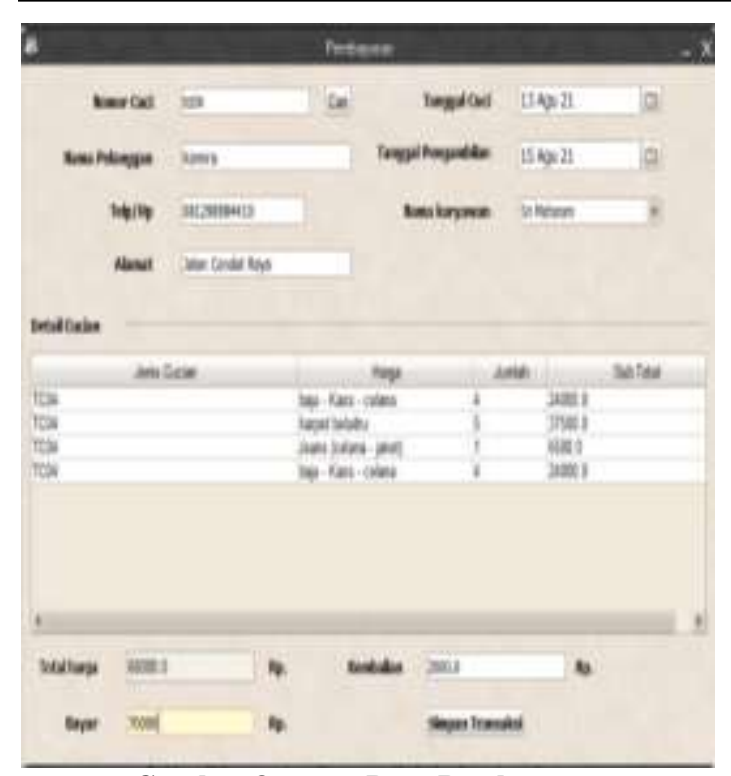

Gambar 8. Form Data Pembayaran

Layar di atas menampilkan tampilan form data pembayaran. Pada layar form data pembayaran untuk meng-input data pembayaran yang terdiri dari Nomor Cuci, Nama Pelanggan, No Telp, Alamat, Tgl Cuci, Tgl Pengambilan, Nama Karyawan, Total Harga, Bayar, dan Kembalian.

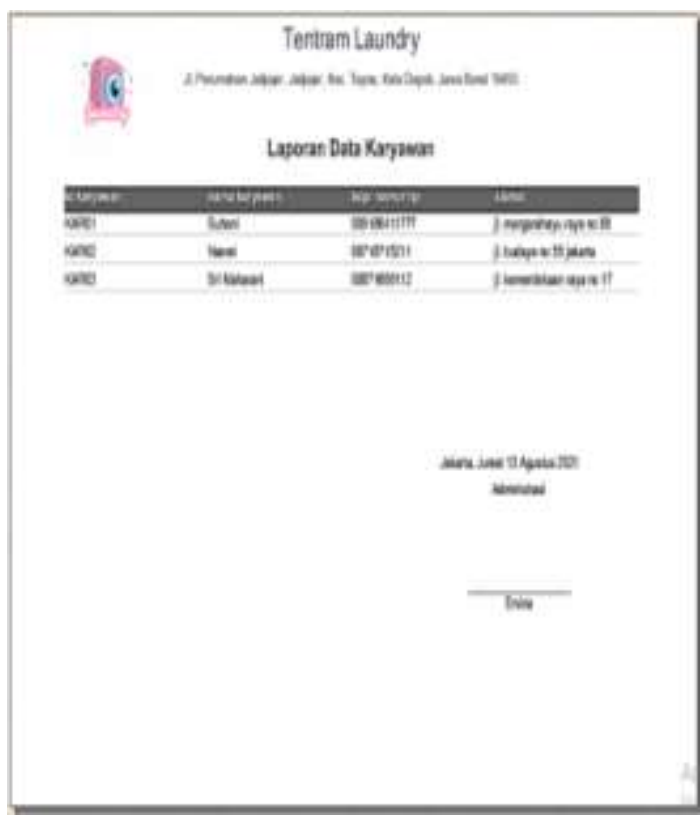

Gambar 9. Laporan Data Karyawan

Layar di atas menampilkan tampilan form laporan data karyawan. Pada layar form data karyawan digunakan untuk mengecek laporan data karyawan terdiri Kode Karyawan, Nama Karyawan, No Telp dan Alamat.

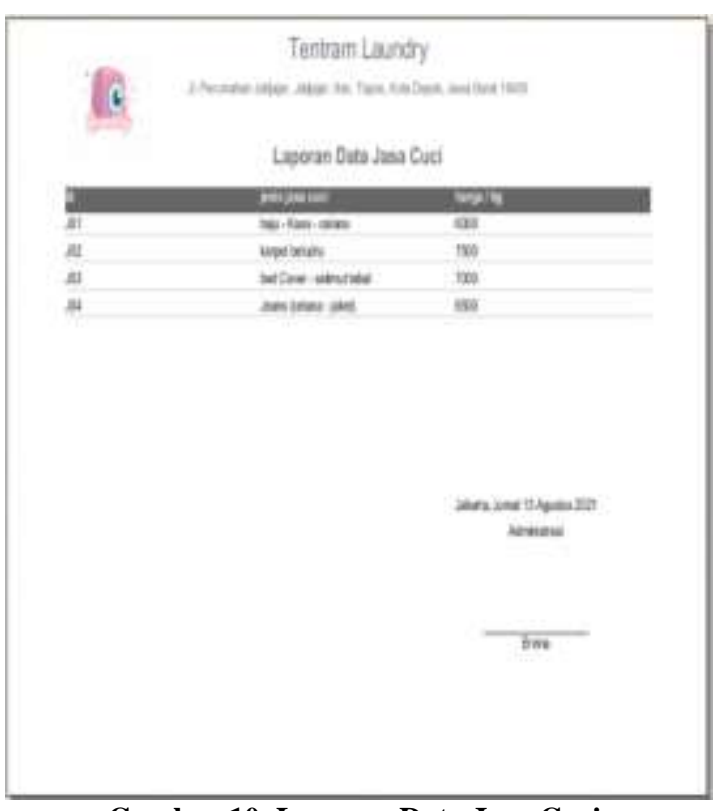

Gambar 10. Laporan Data Jasa Cuci

Layar di atas menampilkan tampilan form laporan data jasa cuci. Pada layar form data jasa cuci digunakan untuk mengecek laporan data jasa cuci terdiri ID Jasa Cuci, Nama, Harga dan Keterangan.

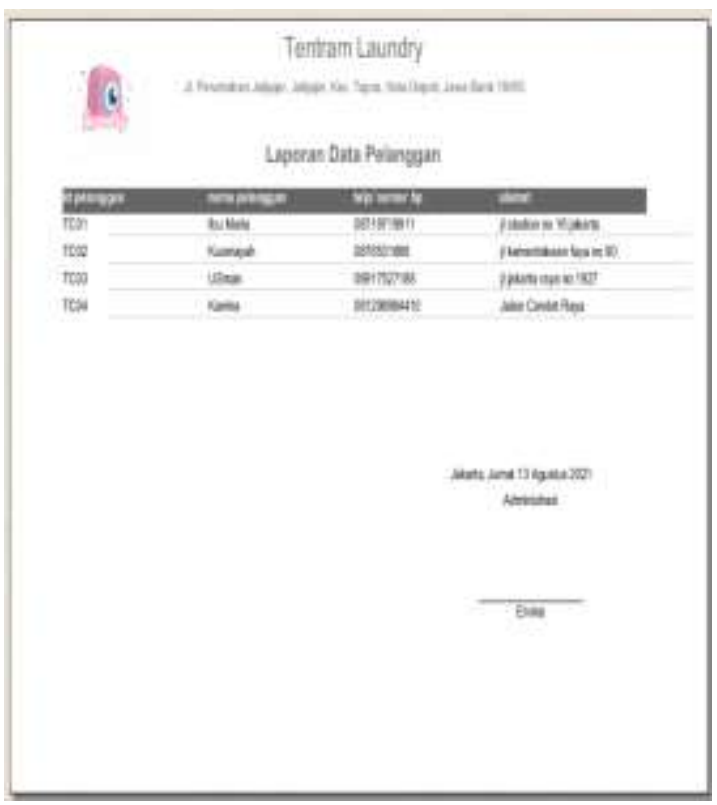

Gambar 11. Laporan Data Pelanggan

Layar di atas menampilkan tampilan form laporan data pelanggan. Pada layar form data pelanggan digunakan untuk mengecek laporan data pelanggan terdiri ID Pelanggan, Nama Pelanggan, No Telp dan Alamat. 


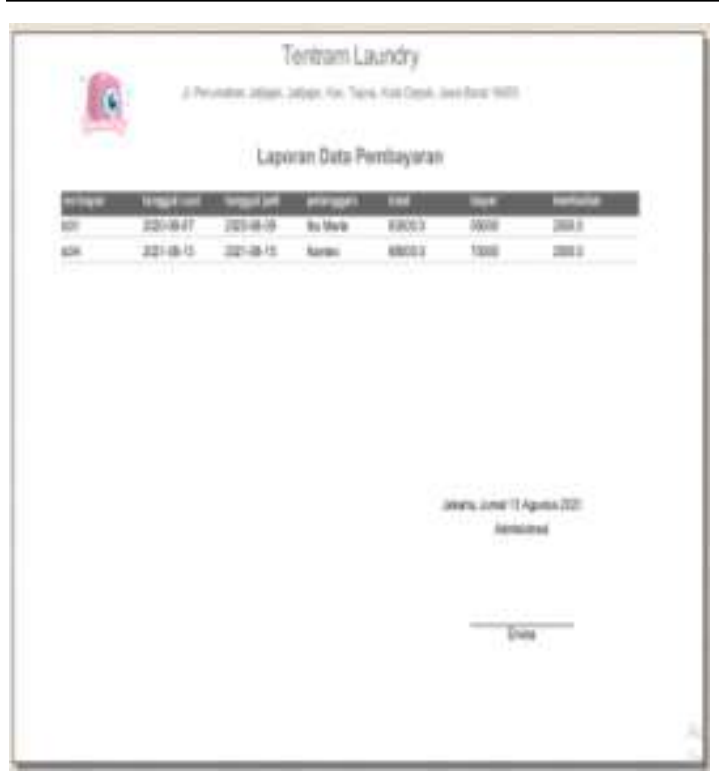

Gambar 12. Laporan Data Pembayaran

Layar di atas menampilkan tampilan form laporan data pembayaran. Pada layar form data pembayaran digunakan untuk mengecek laporan data pembayaran terdiri No Bayar, Tgl Cuci, Tgl Jadi, Nama Pelanggan, Total, Bayar, dan Kembalian.

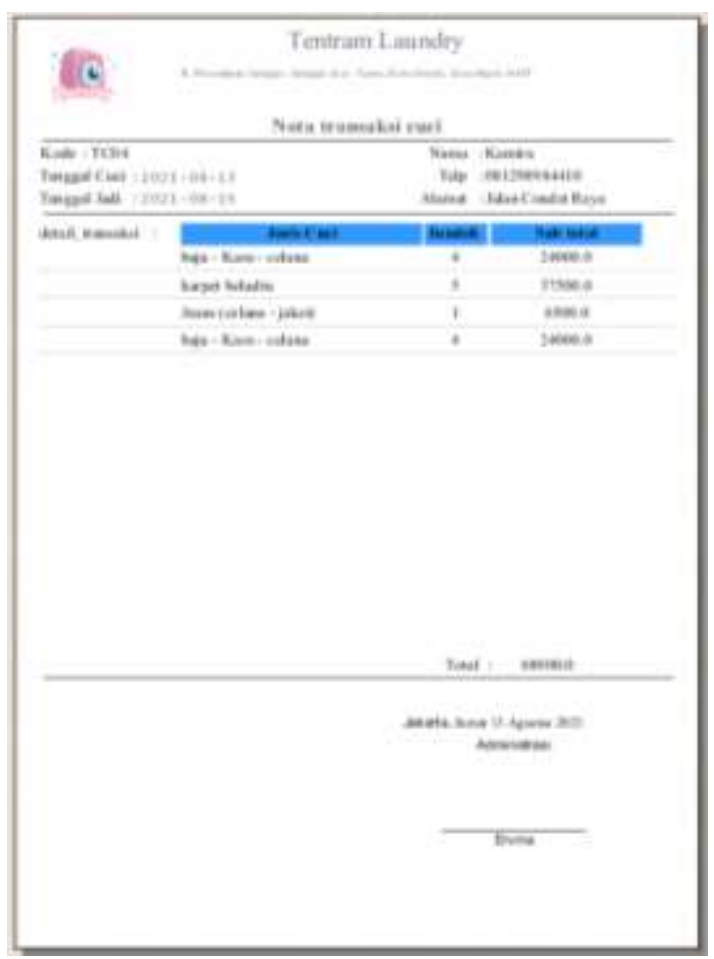

Gambar 13. Transaksi Cuci

Layar di atas menampilkan tampilan nota transaksi cuci. Pada layar nota transaksi cuci terdiri dari Nomor Cuci, Tgl Cuci, Tgl Jadi, Nama Pelanggan, No Telp, Alamat, Jenis Cuci, Jumlah, Sub Total, dan Total Harga.

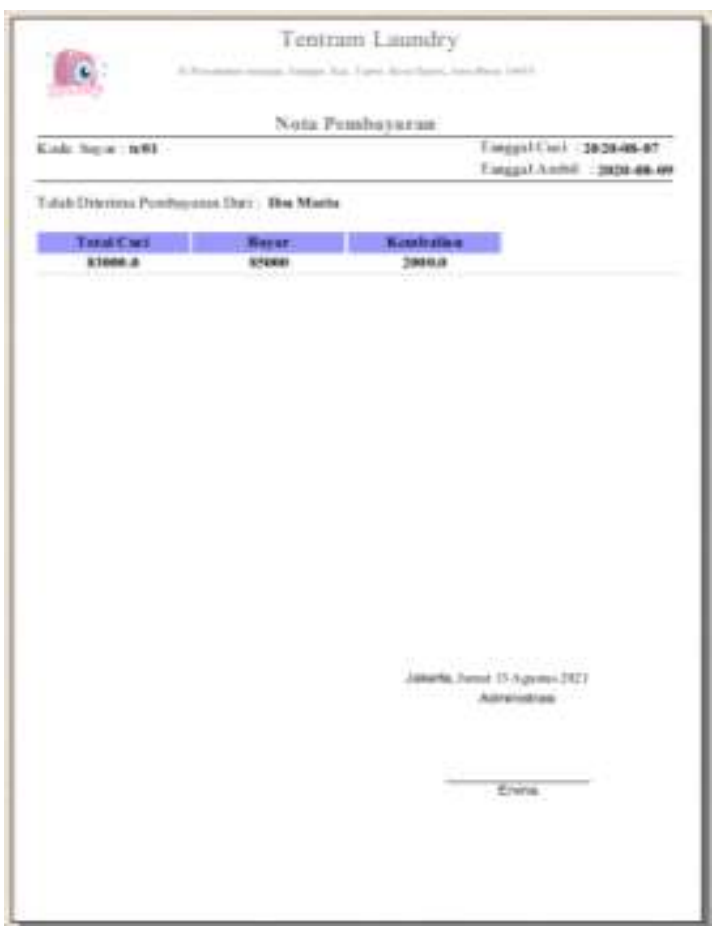

Gambar 14. Nota Pembayaran

Layar di atas menampilkan tampilan nota transaksi. Pada layar nota transaksi terdiri Kode Bayar, Tgl Cuci, Tgl Ambil, Total Cuci, Bayar dan Kembalian.

\section{SIMPULAN DAN SARAN}

Sistem layanan dan managemen data pelanggan yang sedang berjalan di Tentram Laundry masih sederhana, pencatatan datadata pelayanan jasa laundry masih dilakukan secara manual dan belum efektif dalam mampu mengatasi masalah-masalah yang masih sering terjadi.Sarannya adalah sebaiknya sistem ini masih perlu diperbaharui dengan melakukan proses pembagian pelayanan jasa steam motor dan mobil secara keseluruhan dari setiap pelanggan. Hasil implementasi sistem yang telah dibuat dirasakan lebih efektif. Penyimpanan datadata pada media database akan mempercepat dalam pencarian data. Pada proses pembuatan laporan aplikasi ini akan sangat membantu dalam pengolahan data-data yang maksimal dan efisien dalam pembuatan laporan hasil pelayanan jasa laundry sehingga sangat membantu memudahkan tugas dari admin.

Sarannya adalah sistem ini diharapkan untuk dapat dikembangkan pada pengolahan bahan baku yang digunakan untuk laundry, sehingga dapat mencapai serta mewujudkan kinerja yang lebih baik dan maksimal. 


\section{DAFTAR PUSTAKA}

Andriansyah, D. (2018). Penerapan Model Waterfall Pada Sistem Informasi Layanan Jasa Laundry Berbasis Web. Indonesian Journal on Software Engineering (IJSE). https://doi.org/10.31294/ijse.v4i1.6291

Bonny Triangga, M. (2015). Sistem Informasi Pelayanan Jasa Laundry Toko Quin'S Laundry Berbasis Desktop. Jurnal Penelitian Dosen FIKOM (UNDA).

Christian, A., Rizal, K., Alam, N., \& Amir. (2019). Perancangan Sistem Informasi Jasa Cuci Mobil dan Motor. Inti Nusa Mandiri, 14(1), 65-70.

Haqi, B. (2018). Sistem Informasi Pelayanan Jasa Laundry pada Fatma Fresh Berbasis JAVA Netbeans dengan Mengunakan Scan Barcode Android. Prosiding Seminar Nasional Pendidikan KALUNI. https://doi.org/10.30998/prossnp.v1i0.3 5

Husnil Kamil, A. D. (2016). Pembangunan Sistem Informasi Pelayanan Jasa Laundry Berbasis Web Dengan Fitur Mobile Pada 21 Laundry Padang. Seminar Nasional Sains Dan Teknologi Fakultas Teknik Universitas Muhammadiyah Jakarta.
Kotler, P. and K. L. K. (2016). Marketing Management, 15th Edition. New Jersey: Pearson Education.

Niroha, H., Fadillah, M., Izzuddin Al Qassam, M., Puspa Diamanta, N., Dwi Safitri, N., Teknik Informatika dan Komputer, J., \& Negeri Jakarta, P. (2016). Sistem Informasi Laundry Berbasis Metode OOAD. Ijns. Org Indonesian Journal on Networking and Security - Agustus.

Prasojo, M. (2011). Pengantar Sistem Informasi Manajemen . bandung: CV. Remadja Karya.

Putra, N. (2011). Research and Development, Penelitian dan Pengembangan: Suatu Pengantar. Jakarta: PT Raja Grafindo Persada.

Satzinger, J. W., Jackson, R. B., Burd, S. D. (n.d.). System Analysis and Design in A Changing World. USA: Cengage Learning.

Sugiyono. (2016). Metode Penelitian Kuantitatif, Kualitatif dan $R \& D$. Bandung: PT Alfabet.

Sutabri, T. (2012). Analisis Sistem Informasi. Yogyakarta: Andi.

Tyoso, J. S. P. (2016). Sistem Informasi Manajemen. Yogyakarta: DeePublish. 